\title{
Glutamatergic Mechanisms Associated with Seizures and Epilepsy
}

\author{
Melissa Barker-Haliski and H. Steve White \\ Anticonvulsant Drug Development Program, Department of Pharmacology and Toxicology, \\ University of Utah, Salt Lake City, Utah 84108 \\ Correspondence: melissa.barker@utah.edu
}

Epilepsy is broadly characterized by aberrant neuronal excitability. Glutamate is the predominant excitatory neurotransmitter in the adult mammalian brain; thus, much of past epilepsy research has attempted to understand the role of glutamate in seizures and epilepsy. Seizures induce elevations in extracellular glutamate, which then contribute to excitotoxic damage. Chronic seizures can alter neuronal and glial expression of glutamate receptors and uptake transporters, further contributing to epileptogenesis. Evidence points to a shared glutamate pathology for epilepsy and other central nervous system (CNS) disorders, including depression, which is often a comorbidity of epilepsy. Therapies that target glutamatergic neurotransmission are available, but many have met with difficulty because of untoward adverse effects. Better understanding of this system has generated novel therapeutic targets that directly and indirectly modulate glutamatergic signaling. Thus, future efforts to manage the epileptic patient with glutamatergic-centric treatments now hold greater potential.

\section{EXCITOTOXICITY AND EPILEPSY}

ormal neuronal signaling requires a complex orchestra of pre- and postsynaptic events mediated by intracellular signaling and gene expression pathways. Such short- and longterm changes can occur simultaneously and separately, dependently and independently. Normal signaling, however, goes awry in pathological conditions, such as epilepsy. The resulting aberrant cellular and network activity produces a shift in connectivity and synchronicity that contributes to disease progression. In epilepsy, chronic dysynchronous network activity induces extraneous neuronal firing and patho- logical alterations in signaling that may arise from multiple pathways. One factor that is heavily implicated in much of the aberrant signaling and resulting pathology of epilepsy is the neurotransmitter, glutamate. In the following text, the myriad glutamatergic mechanisms related to epilepsy will be explored. Further, present and potential avenues for modulating glutamate transmission for therapeutic gain will be discussed. Although current understanding of epilepsy has relied heavily on a role for glutamate, future efforts to better understand this essential neurotransmitter may result in improved therapeutic treatment strategies and preventative measures for the patient with epilepsy.

Editors: Gregory L. Holmes and Jeffrey L. Noebels

Additional Perspectives on Epilepsy: The Biology of a Spectrum Disorder available at www.perspectivesinmedicine.org

Copyright (C) 2015 Cold Spring Harbor Laboratory Press; all rights reserved; doi: 10.1101/cshperspect.a022863

Cite this article as Cold Spring Harb Perspect Med 2015;5:a022863 
M. Barker-Haliski and H.S. White

\section{EXCITATORY NEUROTRANSMISSION IN THE NORMAL AND EPILEPTIC BRAIN}

Glutamate is the predominant excitatory neurotransmitter of the adult mammalian brain and is critical to normal execution of numerous processes. Calcium-dependent presynaptic release of glutamate into the synaptic cleft is driven in response to neuronal depolarization. Glutamate, like the inhibitory neurotransmitter $\gamma$-aminobutyric acid (GABA), mediates its excitatory effects via several ionotropic and metabotropic receptor subclasses (Fig. 1). Of the postsynaptic ionotropic glutamate receptors, $\alpha$-amino-3-hydroxy-5-methyl-4-isoxazolepropionic acid (AMPA) receptors (AMPARs) are critical to fast excitatory neurotransmission, whereas $N$-methyl-D-aspartate (NMDA) receptors (NMDARs) mediate much of the slow postsynaptic excitatory potentials essential to global

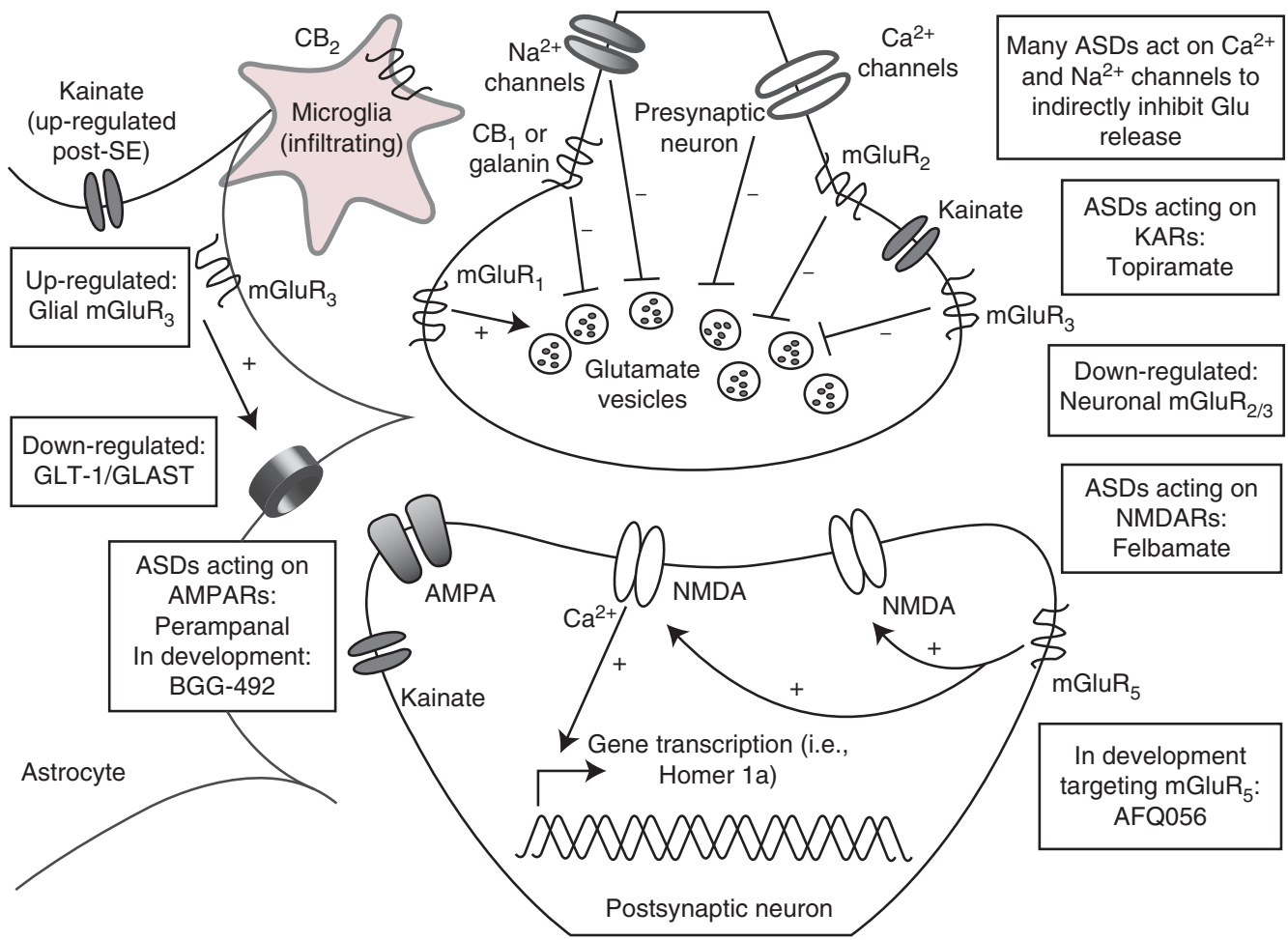

Figure 1. The glutamatergic tripartite synapse. Excitatory afferents project from cortical or hippocampal regions, releasing glutamate into the synaptic cleft. Under normal conditions, synaptic glutamate can signal through ionotropic $\alpha$-amino-3-hydroxy-5-methyl-4-isoxazolepropionic acid receptors (AMPARs), $N$-methyl-D-aspartate receptors (NMDARs), and kainate receptors (KARs), or through metabotropic mGluR I, II, or III class receptors. Synaptic glutamate is subject to reuptake by astrocytes via the glutamate transporters, glutamate transporter 1 (GLT)-1 and L-glutamate/L-aspartate transporter (GLAST). In epilepsy, GLT-1 and GLAST expression is down-regulated, an effect that can contribute to further excitotoxic damage under conditions of chronic seizure-induced glutamate release. Currently approved antiseizure drugs (ASDs) target some aspects of the glutamatergic synapse and more compounds are currently in development to selectively modulate glutamatergic signaling through mGluRs, as well as glial receptors and transporters. Astrocyte-specific strategies to augment GLT-1/GLAST expression in epilepsy, and thereby a decrease in extraneous synaptic levels of excitotoxic glutamate, is also an area of active investigation for therapeutic intervention. Additional areas of therapeutic development include mGluR targeting agents, cannibinoid (CB) receptor targeting compounds, and neuropeptide receptors, all of which are hypothesized to directly and indirectly modulate glutamatergic signaling. SE, Status epilepticus; mGluR, metabotropic glutamate receptor. 
information processing. Glutamate can also interact with an additional ionotropic glutamate receptor, the kainate receptor (KAR). The KAR has a less clearly understood role in neuronal signaling that may include both pre- and postsynaptic modulation of excitatory neurotransmission (Contractor et al. 2000; Lerma and Marques 2013). The effect of glutamate on these receptor subtypes thereby stimulates a number of pre- and postsynaptic events, all of which underlie normal and abnormal neuronal activity.

The majority of fast excitatory synaptic transmission proceeds either through the presynaptic regulation of glutamate release or through the postsynaptic strengthening or weakening of neuronal connections at synapses via changes in AMPAR localization. The cycling of synaptic AMPARs promotes long-term potentiation and long-term depression (Anggono and Huganir 2012). Additionally, homeostatic plasticity facilitates long-duration plastic responses to subcellular modifications in synaptic transmission without large-scale alterations in regional connectivity (Turrigiano 2007, 2012). Neuronal circuit activity and past synaptic activity at individual synapses regulate the number, synaptic localization (externalized or internalized), and subunit composition of AMPARs. Thus, neurons can strengthen or weaken their response to excitatory input. Changes in relative synaptic strength certainly contribute to long-term changes in neurocircuitry within the brain. Synaptic remodeling ultimately contributes to neuronal destabilization, because of the increased or decreased ease with which a postsynaptic neuron can be depolarized by presynaptic input. For this reason, aberrant neuronal activity as seen within an epileptic network likely leads to long-term rewiring within neuronal networks, an effect that contributes to network hyperexcitability associated with epilepsy (Chen et al. 1999; Leite et al. 2005).

To counterbalance these rapid, destabilizing changes at individual spines, neurons also undergo homeostatic plasticity, which can stabilize activity at the individual neuron level and also at the circuit level (Anggono and Huganir 2012), effects that help to maintain a specific "set point" (Turrigiano 2012). When neuronal or circuit activity deviates from this set point, they respond in a manner that attempts to restore activity and reduce excitability. In epilepsy, repeated dysynchronous network activity may modify the circuit "set point," as is observed within the entorhinal cortex-hippocampal microcircuit (Coulter et al. 2011). Mechanistically, extraneous synaptic activity results in enhanced intracellular calcium, gene transcription, and activation of signaling kinases (Seeburg et al. 2008; Goold and Nicoll 2010). Collectively, such changes likely contribute to the hallmarks of temporal lobe epilepsy (TLE), including neuronal loss, gliosis, and mossy fiber sprouting (Leite et al. 2005). These changes may also shift the extent of activity-induced AMPAR accumulation at synapses (Seeburg et al. 2008), which could give rise to enhanced synaptic efficiency or contribute to further aberrant glutamate release. In fact, calcium impermeable GluA2-containing AMPAR expression is increased in rat cerebral cortex following pilocarpine-induced status epilepticus (SE) (Russo et al. 2013), demonstrating a potential long-term shift in neuroplasticity that may contribute to neuroprotection against SE-induced neurotoxicity. With the observed network hyperactivity of epilepsy, the resultant set-point shift may underlie long-term modifications in neuronal connectivity and circuitry to contribute to ictogenesis and epileptogenesis.

\section{METABOTROPIC GLUTAMATE RECEPTOR SUBTYPES, REGULATION, AND ROLE IN ICTOGENESIS AND EPILEPSY}

In addition to postsynaptic ionotropic AMPARs and NMDARs, pre- and postsynaptic metabotropic glutamate receptors (mGluRs) have also been implicated in epilepsy. The mGluRs are divided into three major functional subgroups (Fig. 1). Group I includes presynaptic mGluR1 and postsynaptic mGluR5. Presynaptic mGluR1 can enhance vesicular release of glutamate, whereas postsynaptic mGluR5 can modulate the postsynaptic actions of ionotropic receptors (NMDA/AMPA). In neurons, mGluR5 is physically linked to NMDARs via the proteins Homer, shank, and PSD-95, and is involved in direct phosphorylation of NMDARs. Astrocytes 
also show robust expression of mGluR5 (see Durand et al. 2013). Group II includes mGluR2/3, which reside predominately on the presynaptic terminal and can inhibit presynaptic glutamate release. Following pilocarpine-induced SE, there is a profound down-regulation of presynaptic mGluR2/3 expression in areas CA1 and CA3. This may promote enhanced excitability (Tang et al. 2004; Pacheco Otalora et al. 2006). Additionally, mGluR3 is expressed on astrocytes and regulates the expression of the glutamate transporters L-glutamate/L-aspartate transporter (GLAST) and glutamate transporter (GLT)-1 (Aronica et al. 2003), which are responsible for $>90 \%$ of glutamate reuptake (Rothstein et al. 1994), an effect that can profoundly modulate glutamate levels in the synaptic cleft (Durand et al. 2013). Interestingly, astrocytic mGluR3 expression is up-regulated in TLE (Aronica et al. 2000). Extraneous glutamate release associated with chronic seizure activity likely contributes to the reported mGluR3 expression on astrocytes. Group III metabotropic glutamate receptors function as inhibitory presynaptic receptors and include mGluR4, 6, 7, and 8. Group III mGluRs are up-regulated in seizure and epilepsy models and may reflect a physiologic mechanism to compensate for increased hyperexcitability (Pitsch et al. 2007). Altogether, mGluRs represent a potential mechanism to modulate glutamatergic signaling in epilepsy.

The genetic mutation underlying fragile $\mathrm{X}$ syndrome (FXS), an autism spectrum disorder wherein $\sim 14 \%$ of patients present with seizures (Berry-Kravis et al. 2010), is caused by dysfunction in the fragile $\mathrm{X}$ mental retardation protein (FMRP). FMRP disrupts mGluR5 trafficking to neuronal synapses, an effect that may contribute to seizures associated with FXS (Bardoni et al. 2001). This protein interacts with cellular processes essential to those neuroplasticity processes mediated by group I mGluRs, including mGluR5 (Bardoni et al. 2001). Fragile $\mathrm{X}$ mental retardation 1 (FMR1) knockout mice are susceptible to audiogenic seizures (Pacey et al. 2009), suggesting that mGluR5 plays a role in mediating neuronal hyperexcitability. A role for FMRP-mediated regulation of mGluR5 is also highlighted by the observation of greater de novo gene mutations in epilepsy associated specifically within autism-spectrum disorder- and FMRP-associated genes (Epi4K Consortium et al. 2013). This observation suggests that these pathologies likely converge at the level of glutamatergic neurotransmission and contribute to an imbalance in excitation. Clinical trials currently underway to examine the use of mGluR5 antagonists in the targeted treatment of FXS (Hagerman et al. 2009) will ultimately determine whether mGluR5 antagonists will be effective in the management of FXS-associated seizures, and perhaps other epilepsies.

Expression of group I mGluRs (e.g., mGluR1/5), at excitatory synapses is also regulated by the immediate early gene, Homer $1 a$ (Brakeman et al. 1997). Induction of Homer $1 a$ itself is modulated by NMDAR signaling mechanisms (Tu et al. 1999; Sato et al. 2001). Activation of Homer 1a can result in reduced tyrosine phosphorylation of GluA2-containing AMPARs (Hu et al. 2010; Turrigiano 2012), an effect that can reduce the expression of synaptic AMPARs and contribute to long-term changes in neuroplasticity observed in epilepsy. There is ample evidence for a key role of Homer $1 a$ in seizures and epileptogenesis. In normal rats, Homer 1a expression is up-regulated following acute maximal electroshock (MES) (Fig. 2) (Brakeman et al. 1997; M Barker-Haliski and HS White, unpubl.) and chronic electroconvulsive seizures (Altar et al. 2004). In the kindling model of epilepsy (Potschka et al. 2002), Homer $1 a-$ overexpressing mice show delays in kindling acquisition (Potschka et al. 2002), and Homer la is up-regulated in response to SE (Cavarsan et al. 2012). Homer la protein normally contributes to homeostatic scaling (Hu et al. 2010), which is likely aberrant in chronic seizures (Frank 2014). In addition to the observed dysregulation of Homer $1 a$ in seizure models, expression of other synaptic plasticity-associated immediate early genes (IEGs), including $c$-Fos and Arc, have also been shown to be dysregulated in animal models of chronic seizures (Klein et al. 2004; Christensen et al. 2010). Moreover, such IEG dysregulation is highly conserved in some of the comorbidities of epilepsy, like neuropathic pain (Obara et al. 2013), as well as other instanc- 
A

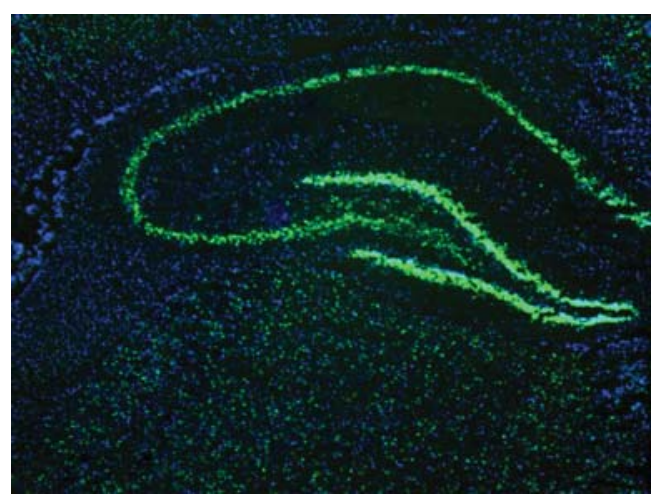

B

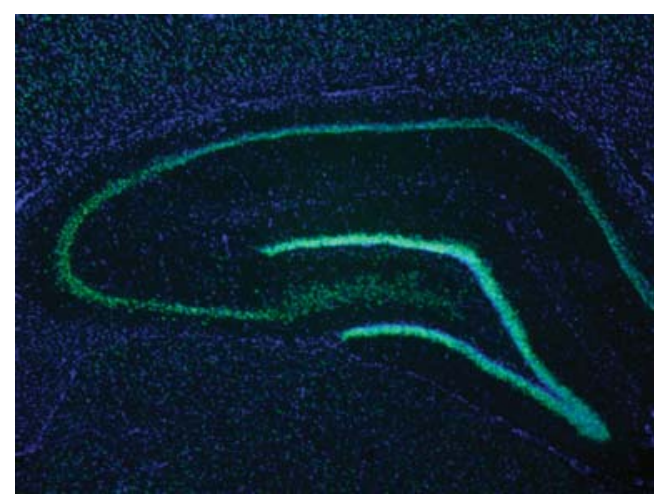

Figure 2. Representative photomicrographs from in situ hybridization histochemistry. Homer 1a messenger RNA (mRNA) expression in dorsal hippocampus of male Sprague-Dawley rats (A) 60 min, and (B) 120 min following maximal electroshock (MES) stimulation (White et al. 1995b; Loscher 1997). Homer 1a mRNA shows robust activity-dependent expression $60 \mathrm{~min}$ and $120 \mathrm{~min}$ following MES (Brakeman et al. 1997) in dorsal hippocampus. In situ hybridization histochemical labeling for Homer 1a mRNA was conducted as previously described for Arc mRNA (Barker-Haliski et al. 2012), with complementary DNA (cDNA) plasmids for Homer 1a provided by Dr. Kristen Keefe, University of Utah. Images were acquired at $2.5 \times$ magnification using a Zeiss Axio Imager.A1 microscope and Axiovision V.4.5 imaging software. Green is Homer $1 a$ mRNA and blue is DAPI nuclear counterstain (Life Technologies, Norwalk, CT).

es of acute glutamatergic excitotoxicity, including methamphetamine-induced neurotoxicity (Barker-Haliski et al. 2012). Glutamatergic excitotoxicity may also induce long-term changes in basal and activity-dependent IEG expression following such an insult (Barker-Haliski et al. 2012). Collectively, these effects on IEG expression likely contribute to further modification of synaptic transmission in epilepsy (Ortuno-Sahagun et al. 2013). Aberrant glutamatergic signaling and chronic excitotoxic damage also leads to changes in IEG expression, all of which likely contribute to seizure maintenance and progression. Additional investigations are clearly required; however, observed changes in IEGs are of interest and suggestive of a novel mechanism underlying ictogenesis and perhaps epileptogenesis that could serve as a potential therapeutic target for the prevention and treatment of epilepsy.

\section{PREVENTION OF EPILEPTOGENESIS THROUGH MODULATION OF GLUTAMATERGIC MECHANISMS}

Evidence for a role of glutamate in seizures and epileptogenesis is found in animal models and humans during SE. For example, SE-induced by high sublethal to lethal doses of nerve agents is associated with excessive acetylcholine accumulation and a secondary recruitment of excitatory glutamatergic signaling (Lallement et al. 1991). SE-induced glutamate release results in overstimulation of glutamate receptors, including NMDARs, sustained long-term seizure activity, and development of seizure-induced brain damage (McDonough and Shih 1997; Dorandeu et al. 2013a). With prolonged SE, GABA receptors are internalized and NMDARs migrate to neuronal synapses (Wasterlain and Chen 2008; Naylor et al. 2013; Wasterlain et al. 2013), all effects that lead to reduced inhibition and hyperexcitability. These SE-induced changes in receptor localization highlight why drugs that target GABAergic neurotransmission likely fail to suppress seizures associated with sustained SE, whereas treatment with NMDAR antagonists in combination with GABA agonists and other agents can often successfully attenuate experimental SE.

NMDAR antagonists like MK-801 or ketamine are able to suppress seizures and be neuroprotective after prolonged SE (Dorandeu 
et al. 2013a,b). Thus, modulation of glutamatergic signaling at the level of NMDARs plays a critical role in mitigating SE-induced damage. The extensive damage associated with prolonged SE is widely appreciated to represent a risk for the development of epilepsy. Longterm remodeling of synaptic connectivity and dendritic morphology mediated by NMDARs may contribute to the onset of spontaneous recurrent seizures. NMDAR subunits undergo posttranscriptional modifications and epigenetic changes in response to SE (Ryley Parrish et al. 2013), effects that contribute to long-lasting changes in circuit connectivity. For these reasons, specifically targeting the glutamatergic system with NMDAR antagonists may effectively prevent epileptogenesis after SE (Osterweil et al. 2013). Moreover, inhibition of brainspecific microRNA-134, which participates in those processes necessary for NMDAR-dependent spine remodeling (Schratt et al. 2006), can prevent spontaneous recurrent seizures months after SE in $>90 \%$ of animals treated; an effect suggesting a strategy to prevent TLE (JimenezMateos et al. 2012). Although not indicative of antiepileptogenesis per se, Sroubek and colleagues (2001) were able to use ketamine to prevent memory deficits associated with pilocarpine-induced SE. Further, Loss and colleagues (2012) observed reductions in postSE-induced anxiety with ketamine treatment. Because growing evidence suggests that certain comorbidities may actually precede epileptogenesis (Kanner et al. 2012; Brooks-Kayal et al. 2013), the ability of NMDAR antagonists to prevent the onset of epilepsy-associated comorbidities (i.e., disease modifying), suggests a role for glutamate excitotoxicity in mediating epileptogenesis and some of the attendant comorbidities.

\section{A ROLE FOR GLIAL REGULATION OF GLUTAMATE IN EPILEPSY}

Investigations to understand the neuronal dysfunction that occurs in epilepsy has led to the development of many antiseizure drugs (ASDs) that modulate neuronal signaling. Although glia were traditionally viewed as mere support cells of the nervous system, growing evidence, and interest in the field, has now firmly established an essential role for glial cells in regulating normal and abnormal neuronal function. Astrocytes actively participate in synaptic signaling by ensheathing neuronal synapses with processes rich in neurotransmitter transporters and receptors that function to buffer synaptic glutamate levels (Halassa et al. 2007). Astrocytes are considered critical to the regulation of extracellular glutamate levels, for example, astrocytes possess the transporters GLAST and GLT-1 necessary for the removal of glutamate from the synapse (Rothstein et al. 1994). In times of excessive seizure activity or another excitotoxic event, extracellular glutamate levels rise, and contribute to the reactive astrocytosis associated with epileptogenesis and other neurotoxic events (Laird et al. 2008; Wetherington et al. 2008; Friend and Keefe 2013). Through the screening of FDA-approved drugs, Rothstein and colleagues showed that the antibacterial, ceftriaxone, could substantially up-regulate GLT1 messenger RNA (mRNA) transcription and exert a neuroprotective effect in an in vivo model of ischemic injury (Rothstein et al. 2005). Moreover, GLT-1-overexpressing mice show a significant reduction in disease severity following pilocarpine-induced SE (Kong et al. 2012), suggesting that targeting glutamate transporters through transcriptional or translational regulation processes could represent an as-yet untapped therapeutic strategy for excitotoxic injury, including epilepsy (Lin et al. 2012). Efforts are now underway to use ceftriaxone to increase expression of glutamate transporters in a variety of preclinical models and clinical disorders associated with glutamate-mediated excitotoxic injury, including ALS (Simantov et al. 1999; Berry et al. 2013), Huntington's disease (Miller et al. 2008), substance-abuse disorders (Sari et al. 2009; Abulseoud et al. 2012), traumatic brain injury (Goodrich et al. 2013), and epilepsy (Jelenkovic et al. 2008; Rawls et al. 2010; Zeng et al.2010). As interest in, and understanding of, glial function in pathological conditions grows, efforts to capitalize on this knowledge will provide significant potential for "glia-centric" therapeutics. 
One of the most characterized instances of astroglial reactivity in epilepsy is that which is observed following SE and during subsequent epileptogenesis in TLE (Gibbons et al. 2013). Astroglial reactivity is defined by hypertrophy, changes in expression of intermediate filaments, such as glial fibrillary acidic protein (GFAP), and morphological changes in astrocytic processes, including elongation and thickening. Following SE, several neuronal and astroglial morphological changes occur within the brain that likely contribute to physiological rearrangement underlying TLE (Engel 1996). In particular, normal glutamate clearance is disrupted because of reduced expression of GLAST and GLT1 (Rothstein et al. 1994; Tanaka et al. 1997). Synaptic glutamate clearance normally requires active reuptake by these transporters, rather than enzymatic degradation; thus, reduction in the expression of these transporters may contribute to ictogenesis and seizure maintenance. Using immunohistochemistry, gross reductions in expression of glial GLAST and GLT-1 is observed in resected hippocampal tissues from patients with pharmacoresistant TLE, whereas the neuronal glutamate transporter, EAAC1, expression is increased (Proper et al. 2002). GLT-1 expression is also reduced in rats following lithium-pilocarpine SE (Crino et al. 2002) and amygdala kindling (Miller et al. 1997), whereas EAAC1 expression is increased. Unfortunately, the observed long-term changes in transporter expression have not been able to clearly reveal those acute changes that initiate epileptogenesis and lead to the development of TLE. Studies 1-2 weeks following SE in astrocytes derived from rats with Kainate (KA)-induced SE, a time in which spontaneous seizure activity is low (Williams et al. 2009), showed no detectable change in the amplitude of glutamate transport currents nor a detectable change in GLT-1 expression (Takahashi et al. 2010). However, it was observed that reactive post-SE astrocytes show an enhanced capacity to clear extracellular glutamate, as measured by a decrease in the decay kinetics of glutamate transport currents (Takahashi et al. 2010). These changes in glutamate transport currents may be caused by alterations in the number and type of synaptic transporters (Takahashi et al. 2010). Although these data obtained following KA-induced SE conflict with transporter expression data collected from human patients with pharmacoresistant TLE (Proper et al. 2002), as well as rodent pilocarpine (Crino et al. 2002) and kindling data (Miller et al. 1997), it is known that KA-induced $\mathrm{SE}$ is associated with a decrease in EAAC1 expression and a moderate increase in astroglial transporter expression. Thus, changes in transporter kinetics observed following KA-induced SE may suggest that SE models result in subcellular response variability. On the other hand, these findings may suggest that acute subcellular changes in glutamate transporter kinetics following SE may promote long-term changes in receptor expression in established TLE. Efforts to clearly define both acute and chronic changes in glutamate receptor function and expression may reveal new avenues for therapeutic intervention.

$\mathrm{SE}$ is also known to affect metabotropic glutamate receptor expression on astrocytes. Following SE, an up-regulation of mGluR1/5glutamate receptors on reactive astrocytes has been reported in a rat model of TLE (Aronica et al. 2000), as well as human TLE patients (Notenboom et al. 2006). How astrocyte-specific changes in glutamate receptor expression following SE can contribute to TLE is still relatively unexplored, but may provide novel mechanisms to bring forth a new class of astrocyte-selective antiseizure therapies (Gibbons et al. 2013). Such glial receptor-specific compounds, like tetrahydrobenzothiepine oxide (THPO) as an inhibitor of astrocyte-specific GABA transporters (White et al. 2002; Schousboe et al. 2014), suggest yet another approach that may lead to a new class of compounds for the prevention of epileptogenesis post-SE.

\section{EPILEPSY-RELATED PHENOTYPES ASSOCIATED WITH ABERRANT GLUTAMATE SIGNALING}

An interesting role for glutamate signaling and glutamate receptors in epilepsy arises from patients with encephalitis because of the development of NMDAR antibodies (Niehusmann 
et al. 2009; Lancaster et al. 2011) and/or antibodies directed against glutamic acid decarboxylase (GAD) (Boronat et al. 2011; Liimatainen et al. 2014). Sometimes, the autoimmune disorder, including the seizures, can be effectively controlled with clinical immunotherapy treatment despite the fact that the antibodies are persistently detectable in sera (Alexopoulos et al. 2011; Lancaster et al. 2011). Such reports of seizures arising from autoimmune attack of glutamate receptors further implicate the glutamatergic system in epilepsy.

In addition to behavioral seizures associated with epilepsy, many patients also suffer from a number of comorbid conditions, which often become more detrimental to a patient's quality of life than the seizures themselves (BrooksKayal et al. 2013). Increasing evidence points to a shared glutamate pathology in several of these comorbid conditions, including those related to depression (Zarate et al. 2006; Niciu et al. 2013) and schizophrenia (Cascella et al. 2009; Merritt et al. 2013). The hypothesized glutamate imbalance in both epilepsy and these specific comorbidities may help explain the efficacy of NMDAR antagonists, like ketamine, in depression (Zarate et al. 2006) and prevention of pathological damage associated with SE (Dorandeu et al. 2013a,b). Such evidence is intriguing given the clinical advances with NMDAR allosteric modulators and subunit-selective antagonists in treating patients with major depression without the risk of adverse psychomimetic effects (Burgdorf et al. 2013; Moskal et al. 2014; Pochwat et al. 2014). Clinical use of these NMDARselective compounds in the patient with epilepsy may provide promising relief from one, if not several, of the comorbidities of epilepsy.

Patients with epilepsy also have a high prevalence of psychosis, ranging from 5\% to $7 \%$ of cases (Gudmundson et al. 1966; Clancey et al. 2014). Clarke and colleagues used a populationbased family study to show that patients with epilepsy have a 5.5-fold greater risk of generalized psychosis and a 8.5 -fold greater risk of developing schizophrenia (Clarke et al. 2012), suggesting that glutamatergic imbalance could underlie both conditions. The potential for psychotic effects should, thus, be considered when initiating treatment with ASDs, especially for those patients with familial or personal history of psychiatric illness. As one study showed, $3.7 \%$ of patients who were treated with topiramate presented with psychotic adverse events (Mula et al. 2003). Such adverse psychotropic effects are also observed with other ASDs, including levetiracetam, tiagabine, vigabatrin, and zonisamide (Piedad et al. 2012). Thus, the potential for adverse psychotic events should be considered when embarking on any ASD-treatment regimen in individuals with a risk of psychosis.

\section{CURRENT ASDS THAT MODULATE GLUTAMATE-MEDIATED NEUROTRANSMISSION}

Because of the importance of maintaining balance between excitation and inhibition, much effort to develop pharmacological therapies for epilepsy have focused on identifying compounds that can modulate these two pathways. To date, several ASDs are available that target the glutamatergic system (Fig. 1). Topiramate suppresses excitatory neurotransmission by attenuating non-NMDA-type glutamate receptor excitatory neurotransmission through inhibition of kainate-evoked currents (Gibbs et al. 2000). Topiramate has also been shown to reduce high basal concentrations of extracellular glutamate in hippocampi of spontaneously epileptic rats (Kanda et al. 1996). In addition to topiramate, the broad-spectrum ASD felbamate can inhibit glutamate currents mediated by NMDARs (Rho et al. 1994). Pregabalin selectively binds to the accessory subunit $\alpha 2 \delta-1$ of voltage-gated calcium channels (Dooley et al. 2007) to block P/ Q-type calcium currents, thereby reducing the calcium-dependent release of glutamate (Dooley et al. 2000). In addition to effects on voltagegated sodium channels, lamotrigine can modulate P/Q-type, N-type, and R-type calcium channels (Wang et al. 1996; Dibue et al. 2013), all of which are expressed on presynaptic nerve terminals, thereby indirectly modulating glutamate release. Other sodium channel blockers, including phenytoin and carbamazepine, also reduce evoked glutamate release through their 
ability to block sodium-evoked calcium influx and excitation-induced glutamate release (Fig. 1). Thus, currently approved ASDs show varying degrees of effects on glutamatergic neurotransmission, effects that can be either direct or indirect.

Although several of the available ASDs indirectly target glutamatergic signaling, glutamate receptor-selective agents have been slower to emerge. As NMDA hypofunction is hypothesized to contribute to schizophrenia, it is no surprise that clinical development of NMDARselective antagonists have met with difficulty owing to adverse behavioral effects (Wada et al. 1992). However, results obtained with selective NMDAR antagonists in depression suggest that it may be possible to selectively target NMDAR for therapeutic gain (see above). Of all ASDs currently approved for clinical use, only felbamate possesses any substantial effects on NMDARs (Rho et al. 1994; White et al. 1995a; Kleckner et al. 1999; Harty and Rogawski 2000). Conversely, modulation of AMPARs may be a more promising clinical target because modulation of AMPAR, but not NMDAR (Hunt and Castillo 2012), signaling exerts fewer effects on neuroplasticity (Goda and Stevens 1996) and has greater potential to modulate hyperexcitability without potential for psychosis (Rogawski 2013). For these reasons, efforts to develop AMPAR-selective agents resulted in clinical approval of perampanel as the first-inclass glutamate system-selective drug for epilepsy (Hanada et al. 2011; Loscher and Schmidt 2012; Rheims and Ryvlin 2013; Rogawski 2013). Perampanel is a noncompetitive AMPAR antagonist (Rheims and Ryvlin 2013) that decreases neuronal excitability and synchronization characteristic of epileptiform activity (Rogawski 2013).

\section{EMERGING MECHANISMS FOR POTENTIAL THERAPIES THAT MODULATE THE GLUTAMATE SYSTEM}

Many other agents that directly target nonNMDA-type glutamate receptors are now in preclinical and clinical development in an effort to exploit this mechanism to reduce hyperex- citability in the epileptic brain (Alexander and Godwin 2006; Faught 2014). Although not critically addressed in this review, KARs represent another key class of glutamate receptors that may play a role in epilepsy, and recent evidence indicates that these receptors are up-regulated in astrocytes in response to SE (Vargas et al. 2013). However, whether these receptors are functional and actively contribute to seizures remains to be determined, but could suggest that selectively targeting astrocytic processes that contribute to glutamate release could be a novel therapeutic target for the treatment of epilepsy (Gibbons et al. 2013). Additionally, selurampanel (BGG492; Fig. 2) is an AMPA/ KA-receptor antagonist (Faught 2014) undergoing clinical trials in patients with partial (ClinicalTrials.gov Identifier NCT01338805) and photosensitive epilepsy (ClinicalTrials.gov Identifier NCT00784212). The approval of perampanel and knowledge of the glutamatergic system gained over the last several decades provides strong support that non-NMDA-type glutamate receptors can be effectively manipulated to manage epilepsy.

More promising for the patient with epilepsy, however, is the potential for indirect modulation of the glutamate system through alternative strategies that have yet to be clinically deployed in the therapeutic arsenal. The following targets and mechanisms to modulate the glutamate system potentially offer first-in-class therapies for the patient with epilepsy and provide promise for the $\sim 30 \%$ of patients resistant to current therapies (Brodie and Kwan 2002).

In addition to efforts to increase transcriptional up-regulation of glutamate transporters, like GLT-1 (see above), other strategies to modulate glutamate transporters include efforts to exploit the neuropeptide system. Neuropeptides have long been known to possess endogenous anticonvulsant properties and may also represent a unique therapeutic strategy for the patient with epilepsy (White et al. 2009; Zhang et al. 2009). As an example, galanin receptors are notably up-regulated on glial cells following neuronal injury (Cortes et al. 1990; Xu et al. 1992), and galanin itself possesses significant anticonvulsant properties (Mazarati et al. 1992, 1998; 
Lin et al. 2003) likely because of indirect modulation of presynaptic glutamate release (BenAri 1990; Kinney et al. 1998). Galanin analogs have shown preclinical efficacy in various seizure models (White et al. 2009; Jequier Gygax et al. 2014); however, the true test of this strategy will necessarily have to await clinical data from appropriately designed clinical trials.

The endocannabinoid system has also emerged as a novel therapeutic strategy to indirectly modulate glutamatergic signaling. The cannabinoid receptors $(\mathrm{CB})_{1}$ and $\mathrm{CB}_{2}$, are expressed on both glia and neurons (Stella 2010) and $\mathrm{CB}_{1}$ receptors are regulated through glutamatergic mechanisms. Although $\mathrm{CB}_{1}$ receptors are highly expressed on GABAergic interneurons, classical effects of cannabinoids are presumed to be mediated through $\mathrm{CB}_{1}$ receptors expressed on glutamatergic principal neurons (Monory et al. 2007; Stella 2010). $\mathrm{CB}_{2}$ receptors are not highly expressed in the healthy brain (see Stella 2010), but $\mathrm{CB}_{2}$ receptors are up-regulated on infiltrating microglia in response to CNS injury and inflammation (Fig. 2) (Maresz et al. 2005). These observations provide a contextual therapeutic target in epilepsy (i.e., microglia that are activated in response to seizures) (Fig. 2) (Vezzani et al. 2011). Thus, cannabinoids likely act by indirectly modulating glutamatergic transmission via neuronal $\mathrm{CB}_{1}$ receptors and indirectly confer anti-inflammatory effects through microglial $\mathrm{CB}_{2}$ receptors. Even though well-validated preclinical data on the effects of cannabidiol in epilepsy and seizure models is sparse, that which is available suggests efficacy of cannabidiol in various in vitro and in vivo seizure models (Consroe et al. 1982; Jones et al. 2010, 2012). These reasons, when coupled with anecdotal evidence in human patients with drug-refractory epilepsy, may suggest a potential clinical benefit for high-cannabidiol containing marijuana extracts in controlling difficultto-treat epilepsies in children (Porter and Jacobson 2013). Clinical trials in children with Dravet's syndrome are underway (ClinicalTrials.gov Identifier NCT02091375 and NCT02091206) and these data, as well as results from earlier tolerability studies in a small population of adult epilepsy patients (Cunha et al. 1980), are impor- tant for understanding the role of $\mathrm{CB}$ receptors in epilepsy.

In addition to anecdotal efficacy of cannabidiol itself, combination studies may suggest potential synergism of $\mathrm{CB}$ receptor-targeting agents used in combination with approved ASDs. Luszczki and colleagues (2011, 2013) used the mouse MES test to examine the protective effects of the general $\mathrm{CB}$ receptor agonist, WIN 55,212-2, in combination with various ASDs. They observed a potentiated anticonvulsant efficacy with several ASDs in this test in the presence of WIN $(5 \mathrm{mg} / \mathrm{kg})$, specifically WIN $55,212-2$ in combination with carbamazepine and valproate (Luszczki et al. 2011), lamotrigine, pregabalin, and topiramate (Luszczki et al. 2013). Importantly, the synergism was not caused by changes in brain (Luszczki et al. 2011) or plasma (Luszczki et al. 2013) concentration of the ASDs themselves, but likely arose from convergent suppressive effects on glutamatergic neurotransmission (Fig. 1). These drug combination studies, therefore, suggest potential synergistic action of $\mathrm{CB}$ agonists with some ASDs, which may also provide clinical benefit for seizure control. However, although combinations with second-generation ASDs resulted in no significant adverse motor effects (Luszczki et al. 2013), combination with first-generation ASDs resulted in significant impairments in motor coordination, muscle strength, and longterm memory (Luszczki et al. 2011) suggesting that the combination of WIN 55,212-2 with some ASDs results in a negative narrowing of the therapeutic window. As such, additional preclinical and clinical investigations are still required before the therapeutic potential of $\mathrm{CB} /$ ASD combination therapies can be clearly defined. Whether CB agonist combination therapies with second- and third-generation ASDs, as well as glutamate-selective compounds, will prove useful in the management of epilepsy is certainly of clinical importance and deserving of further study.

\section{CONCLUDING REMARKS}

Taken together, substantial evidence shows that glutamate plays a pivotal role in normal neuro- 
nal signaling. Moreover, excess glutamate release associated with recurrent seizures and observed in chronic epilepsy leads to long-term alterations in normal neuronal signaling and network connectivity. There is much preclinical and clinical evidence supporting the therapeutic potential of treatments that modulate glutamatergic signaling in the management of epilepsy. As a result, new targets, including those on astrocytes and microglia, are emerging that may offer a means to modulate glutamate in ways that will avoid some of the hurdles associated with previous attempts to target glutamate receptors themselves. Although prior efforts to target the glutamate system in epilepsy have been slow to provide clinically relevant options, the potential for future development of therapies that selectively target the glutamate system is promising.

\section{REFERENCES}

Abulseoud OA, Miller JD, Wu J, Choi DS, Holschneider DP. 2012. Ceftriaxone upregulates the glutamate transporter in medial prefrontal cortex and blocks reinstatement of methamphetamine seeking in a condition place preference paradigm. Brain Res 1456: 14-21.

Alexander GM, Godwin DW. 2006. Unique presynaptic and postsynaptic roles of group II metabotropic glutamate receptors in the modulation of thalamic network activity. Neuroscience 141: 501-513.

Alexopoulos H, Kosmidis ML, Dalmau J, Dalakas MC. 2011. Paraneoplastic anti-NMDAR encephalitis: Longterm follow-up reveals persistent serum antibodies. $J$ Neurol 258: 1568-1570.

Altar CA, Laeng P, Jurata LW, Brockman JA, Lemire A, Bullard J, Bukhman YV, Young TA, Charles V, Palfreyman MG. 2004. Electroconvulsive seizures regulate gene expression of distinct neurotrophic signaling pathways. J Neurosci 24: 2667-2677.

Anggono V, Huganir RL. 2012. Regulation of AMPA receptor trafficking and synaptic plasticity. Curr Opin Neurobiol 22: 461-469.

Aronica E, van Vliet EA, Mayboroda OA, Troost D, da Silva FH, Gorter JA. 2000. Upregulation of metabotropic glutamate receptor subtype mGluR3 and mGluR5 in reactive astrocytes in a rat model of mesial temporal lobe epilepsy. Eur J Neurosci 12: 2333-2344.

Aronica E, Gorter JA, Ijlst-Keizers H, Rozemuller AJ, Yankaya B, Leenstra S, Troost D. 2003. Expression and functional role of mGluR3 and mGluR5 in human astrocytes and glioma cells: Opposite regulation of glutamate transporter proteins. Eur J Neurosci 17: 2106-2118.

Bardoni B, Schenck A, Mandel JL. 2001. The fragile X mental retardation protein. Brain Res Bull 56: 375-382.
Barker-Haliski ML, Oldenburger K, Keefe KA. 2012. Disruption of subcellular Arc/Arg 3.1 mRNA expression in striatal efferent neurons following partial monoamine loss induced by methamphetamine. JNeurochem 123: 845-855.

Ben-Ari Y. 1990. Galanin and glibenclamide modulate the anoxic release of glutamate in rat CA3 hippocampal neurons. Eur J Neurosci 2: 62-68.

Berry JD, Shefner JM, Conwit R, Schoenfeld D, Keroack M, Felsenstein D, Krivickas L, David WS, Vriesendorp F, Pestronk A, et al. 2013. Design and initial results of a multi-phase randomized trial of ceftriaxone in amyotrophic lateral sclerosis. PLoS ONE 8: e61177.

Berry-Kravis E, Raspa M, Loggin-Hester L, Bishop E, Holiday D, Bailey DB. 2010. Seizures in fragile X syndrome: Characteristics and comorbid diagnoses. Am J Intellect Dev Disabil 115: 461-472.

Boronat A, Sabater L, Saiz A, Dalmau J, Graus F. 2011. $\mathrm{GABA}_{\mathrm{B}}$ receptor antibodies in limbic encephalitis and anti-GAD-associated neurologic disorders. Neurology 76: $795-800$.

Brakeman PR, Lanahan AA, O'Brien R, Roche K, Barnes CA, Huganir RL, Worley PF. 1997. Homer: A protein that selectively binds metabotropic glutamate receptors. Nature 386: 284-288.

Brodie MJ, Kwan P. 2002. Staged approach to epilepsy management. Neurology 58: 2S-8S.

Brooks-Kayal AR, Bath KG, Berg AT, Galanopoulou AS, Holmes GL, Jensen FE, Kanner AM, O'Brien TJ, Whittemore VH, Winawer MR, et al. 2013. Issues related to symptomatic and disease-modifying treatments affecting cognitive and neuropsychiatric comorbidities of epilepsy. Epilepsia 54: 44-60.

Burgdorf J, Zhang XL, Nicholson KL, Balster RL, Leander JD, Stanton PK, Gross AL, Kroes RA, Moskal JR. 2013. GLYX-13, a NMDA receptor glycine-site functional partial agonist, induces antidepressant-like effects without ketamine-like side effects. Neuropsychopharmacology 38: 729-742.

Cascella NG, Schretlen DJ, Sawa A. 2009. Schizophrenia and epilepsy: Is there a shared susceptibility? Neurosci Res 63: 227-235.

Cavarsan CF, Tescarollo F, Tesone-Coelho C, Morais RL, Motta FL, Blanco MM, Mello LE. 2012. Pilocarpine-induced status epilepticus increases Homerla and changes mGluR5 expression. Epilepsy Res 101: 253-260.

Chen K, Baram TZ, Soltesz I. 1999. Febrile seizures in the developing brain result in persistent modification of neuronal excitability in limbic circuits. Nat Med 5: 888-894.

Christensen KV, Leffers H, Watson WP, Sanchez C, Kallunki P, Egebjerg J. 2010. Levetiracetam attenuates hippocampal expression of synaptic plasticity-related immediate early and late response genes in amygdala-kindled rats. BMC Neurosci 11: 9.

Clancy MJ, Clarke MC, Connor DJ, Cannon M, Cotter DR. 2014. The prevalence of psychosis in epilepsy: A systematic review and meta-analysis. BMC Psychiatry 14: 75.

Clarke MC, Tanskanen A, Huttunen MO, Clancy M, Cotter DR, Cannon M. 2012. Evidence for shared susceptibility to epilepsy and psychosis: A population-based family study. Biol Psychiatry 71: 836-839. 
Consroe P, Benedito MA, Leite JR, Carlini EA, Mechoulam R. 1982. Effects of cannabidiol on behavioral seizures caused by convulsant drugs or current in mice. Eur J Pharmacol 83: 293-298.

Contractor A, Swanson GT, Sailer A, O'Gorman S, Heinemann SF. 2000. Identification of the kainate receptor subunits underlying modulation of excitatory synaptic transmission in the CA3 region of the hippocampus. $J$ Neurosci 20: 8269-8278.

Cortes R, Ceccatelli S, Schalling M, Hokfelt T. 1990. Differential effects of intracerebroventricular colchicine administration on the expression of mRNAs for neuropeptides and neurotransmitter enzymes, with special emphasis on galanin: An in situ hybridization study. Synapse 6: $369-391$

Coulter DA, Yue C, Ang CW, Weissinger F, Goldberg E, Hsu FC, Carlson GC, Takano H. 2011. Hippocampal microcircuit dynamics probed using optical imaging approaches. J Physiol 589: 1893-1903.

Crino PB, Jin H, Shumate MD, Robinson MB, Coulter DA, Brooks-Kayal AR. 2002. Increased expression of the neuronal glutamate transporter (EAAT3/EAAC1) in hippocampal and neocortical epilepsy. Epilepsia 43: 211-218.

Cunha JM, Carlini EA, Pereira AE, Ramos OL, Pimentel C, Gagliardi R, Sanvito WL, Lander N, Mechoulam R. 1980. Chronic administration of cannabidiol to healthy volunteers and epileptic patients. Pharmacology 21: 175-185.

Dibue M, Kamp MA, Alpdogan S, Tevoufouet EE, Neiss WF, Hescheler J, Schneider T. 2013. Ca 2.3 (R-type) calcium channels are critical for mediating anticonvulsive and neuroprotective properties of lamotrigine in vivo. Epilepsia 54: 1542-1550.

Dooley DJ, Mieske CA, Borosky SA. 2000. Inhibition of $\mathrm{K}^{+}$. evoked glutamate release from rat neocortical and hippocampal slices by gabapentin. Neurosci Lett 280: 107110.

Dooley DJ, Taylor CP, Donevan S, Feltner D. 2007. $\mathrm{Ca}^{2+}$ channel $\alpha 2 \delta$ ligands: Novel modulators of neurotransmission. Trends Pharmacol Sci 28: 75-82.

Dorandeu F, Barbier L, Dhote F, Testylier G, Carpentier P. 2013a. Ketamine combinations for the field treatment of soman-induced self-sustaining status epilepticus. Review of current data and perspectives. Chem Biol Interact 203: 154-159.

Dorandeu F, Dhote F, Barbier L, Baccus B, Testylier G. 2013b. Treatment of status epilepticus with ketamine, are we there yet? CNS Neurosci Ther 19: 411-427.

Durand D, Carniglia L, Caruso C, Lasaga M. 2013. mGlu3 receptor and astrocytes: Partners in neuroprotection. Neuropharmacology 66: 1-11.

Engel J Jr. 1996. Introduction to temporal lobe epilepsy. Epilepsy Res 26: 141-150.

Epi4K Consortium and an Epilepsy Phenome/Genome Project; Allen AS, Berkovic SF, Cossette P, Delanty N, Dlugos D, Eichler EE, Epstein MP, et al. 2013. De novo mutations in epileptic encephalopathies. Nature 501: 217-221.

Faught E. 2014. BGG492 (selurampanel), an AMPA/kainate receptor antagonist drug for epilepsy. Expert Opin Investig Drugs 23: 107-113.
Frank CA. 2014. How voltage-gated calcium channels gate forms of homeostatic synaptic plasticity. Front Cell Neurosci 8: 40.

Friend DM, Keefe KA. 2013. Glial reactivity in resistance to methamphetamine-induced neurotoxicity. J Neurochem 125: $566-574$.

Gibbons MB, Smeal RM, Takahashi DK, Vargas JR, Wilcox KS. 2013. Contributions of astrocytes to epileptogenesis following status epilepticus: Opportunities for preventive therapy? Neurochem Int 63: 660-669.

Gibbs JW III, Sombati S, DeLorenzo RJ, Coulter DA. 2000. Cellular actions of topiramate: Blockade of kainateevoked inward currents in cultured hippocampal neurons. Epilepsia 41: S10-16.

Goda Y, Stevens CF. 1996. Synaptic plasticity: The basis of particular types of learning. Curr Biol 6: 375-378.

Goodrich GS, Kabakov AY, Hameed MQ, Dhamne SC, Rosenberg PA, Rotenberg A. 2013. Ceftriaxone treatment after traumatic brain injury restores expression of the glutamate transporter, GLT-1, reduces regional gliosis, and reduces post-traumatic seizures in the rat. J Neurotrauma 30: 1434-1441.

Goold CP, Nicoll RA. 2010. Single-cell optogenetic excitation drives homeostatic synaptic depression. Neuron 68: 512-528.

Gudmundsson G. 1996. Epilepsy in Iceland. A clinical and epidemiological investigation. Acta Neurol Scand 43 (Suppl): 1-124.

Hagerman RJ, Berry-Kravis E, Kaufmann WE, Ono MY, Tartaglia N, Lachiewicz A, Kronk R, Delahunty C, Hessl D, Visootsak J, et al. 2009. Advances in the treatment of fragile X syndrome. Pediatrics 123: 378-390.

Halassa MM, Fellin T, Haydon PG. 2007. The tripartite synapse: Roles for gliotransmission in health and disease. Trends Mol Med 13: 54-63.

Hanada T, Hashizume Y, Tokuhara N, Takenaka O, Kohmura N, Ogasawara A, Hatakeyama S, Ohgoh M, Ueno M, Nishizawa Y. 2011. Perampanel: A novel, orally active, noncompetitive AMPA-receptor antagonist that reduces seizure activity in rodent models of epilepsy. Epilepsia 52: 1331-1340.

Harty TP, Rogawski MA. 2000. Felbamate block of recombinant $N$-methyl-D-aspartate receptors: Selectivity for the NR2B subunit. Epilepsy Res 39: 47-55.

Hu JH, Park JM, Park S, Xiao B, Dehoff MH, Kim S, Hayashi T, Schwarz MK, Huganir RL, Seeburg PH, et al. 2010. Homeostatic scaling requires group I mGluR activation mediated by Homerla. Neuron 68: 1128-1142.

Hunt DL, Castillo PE. 2012. Synaptic plasticity of NMDA receptors: Mechanisms and functional implications. Curr Opin Neurobiol 22: 496-508.

Jelenkovic AV, Jovanovic MD, Stanimirovic DD, Bokonjic DD, Ocic GG, Boskovic BS. 2008. Beneficial effects of ceftriaxone against pentylenetetrazole-evoked convulsions. Exp Biol Med (Maywood) 233: 1389-1394.

Jequier Gygax M, Klein BD, White HS, Kim M, Galanopoulou AS. 2014. Efficacy and tolerability of the galanin analog NAX 5055 in the multiple-hit rat model of symptomatic infantile spasms. Epilepsy Res 108: 98-108.

Jimenez-Mateos EM, Engel T, Merino-Serrais P, McKiernan RC, Tanaka K, Mouri G, Sano T, O’Tuathaigh C, Wad- 
dington JL, Prenter S, et al. 2012. Silencing microRNA134 produces neuroprotective and prolonged seizuresuppressive effects. Nat Med 18: 1087-1094.

Jones NA, Hill AJ, Smith I, Bevan SA, Williams CM, Whalley BJ, Stephens GJ. 2010. Cannabidiol displays antiepileptiform and antiseizure properties in vitro and in vivo. $J$ Pharmacol Exp Ther 332: 569-577.

Jones NA, Glyn SE, Akiyama S, Hill TD, Hill AJ, Weston SE, Burnett MD, Yamasaki Y, Stephens GJ, Whalley BJ, et al. 2012. Cannabidiol exerts anti-convulsant effects in animal models of temporal lobe and partial seizures. Seizure 21: $344-352$.

Kanda T, Kurokawa M, Tamura S, Nakamura J, Ishii A, Kuwana Y, Serikawa T, Yamada J, Ishihara K, Sasa M. 1996. Topiramate reduces abnormally high extracellular levels of glutamate and aspartate in the hippocampus of spontaneously epileptic rats (SER). Life Sci 59: 1607-1616.

Kanner AM, Schachter SC, Barry JJ, Hersdorffer DC, Mula M, Trimble M, Hermann B, Ettinger AE, Dunn D, Caplan R, et al. 2012. Depression and epilepsy, pain and psychogenic non-epileptic seizures: Clinical and therapeutic perspectives. Epilepsy Behav 24: 169-181.

Kinney GA, Emmerson PJ, Miller RJ. 1998. Galanin receptor-mediated inhibition of glutamate release in the arcuate nucleus of the hypothalamus. J Neurosci 18: 34893500.

Kleckner NW, Glazewski JC, Chen CC, Moscrip TD. 1999. Subtype-selective antagonism of $\mathrm{N}$-methyl-D-aspartate receptors by felbamate: Insights into the mechanism of action. J Pharmacol Exp Ther 289: 886-894.

Klein BD, Fu YH, Ptacek LJ, White HS. 2004. c-Fos immunohistochemical mapping of the audiogenic seizure network and tonotopic neuronal hyperexcitability in the inferior colliculus of the Frings mouse. Epilepsy Res 62: $13-25$.

Kong Q, Takahashi K, Schulte D, Stouffer N, Lin Y, Lin CL. 2012. Increased glial glutamate transporter EAAT2 expression reduces epileptogenic processes following pilocarpine-induced status epilepticus. Neurobiol Dis 47: $145-154$.

Laird MD, Vender JR, Dhandapani KM. 2008. Opposing roles for reactive astrocytes following traumatic brain injury. Neurosignals 16: 154-164.

Lallement G, Carpentier P, Collet A, Pernot-Marino I, Baubichon D, Blanchet G. 1991. Effects of soman-induced seizures on different extracellular amino acid levels and on glutamate uptake in rat hippocampus. Brain Res 563: 234-240.

Lancaster E, Martinez-Hernandez E, Dalmau J. 2011. Encephalitis and antibodies to synaptic and neuronal cell surface proteins. Neurology 77: 179-189.

Leite JP, Neder L, Arisi GM, Carlotti CG Jr, Assirati JA, Moreira JE. 2005. Plasticity, synaptic strength, and epilepsy: What can we learn from ultrastructural data? Epilepsia 46: 134-141.

Lerma J, Marques JM. 2013. Kainate receptors in health and disease. Neuron 80: 292-311.

Liimatainen S, Peltola J, Hietaharju A, Sabater L, Lang B, 2014. Lack of antibodies to NMDAR or VGKC-complex in GAD and cardiolipin antibody-positive refractory epilepsy. Epilepsy Res 108: 592-596.
Lin EJ, Richichi C, Young D, Baer K, Vezzani A, During MJ. 2003. Recombinant AAV-mediated expression of galanin in rat hippocampus suppresses seizure development. Eur J Neurosci 18: 2087-2092.

Lin CL, Kong Q, Cuny GD, Glicksman MA. 2012. Glutamate transporter EAAT2: A new target for the treatment of neurodegenerative diseases. Future Med Chem 4: 16891700.

Loscher W. 1997. Animal models of intractable epilepsy. Prog Neurobiol 53: 239-258.

Loscher W, Schmidt D. 2012. Epilepsy: Perampanel—New promise for refractory epilepsy? Nat Rev Neurol 8: 661662.

Loss CM, Cordova SD, de Oliveira DL. 2012. Ketamine reduces neuronal degeneration and anxiety levels when administered during early life-induced status epilepticus in rats. Brain Res 1474: 110-117.

Luszczki JJ, Misiuta-Krzesinska M, Florek M, Tutka P, Czuczwar SJ. 2011. Synthetic cannabinoid WIN 55,2122 mesylate enhances the protective action of four classical antiepileptic drugs against maximal electroshock-induced seizures in mice. Pharmacol Biochem Behav 98: 261-267.

Luszczki JJ, Wlaz A, Karwan S, Florek-Luszczki M, Czuczwar SJ. 2013. Effects of WIN 55,212-2 mesylate on the anticonvulsant action of lamotrigine, oxcarbazepine, pregabalin and topiramate against maximal electroshock-induced seizures in mice. Eur J Pharmacol 720: 247-254.

Maresz K, Carrier EJ, Ponomarev ED, Hillard CJ, Dittel BN. 2005. Modulation of the cannabinoid $\mathrm{CB}_{2}$ receptor in microglial cells in response to inflammatory stimuli. $J$ Neurochem 95: 437-445.

Mazarati AM, Halaszi E, Telegdy G. 1992. Anticonvulsive effects of galanin administered into the central nervous system upon the picrotoxin-kindled seizure syndrome in rats. Brain Res 589: 164-166.

Mazarati AM, Liu H, Soomets U, Sankar R, Shin D, Katsumori H, Langel U, Wasterlain CG. 1998. Galanin modulation of seizures and seizure modulation of hippocampal galanin in animal models of status epilepticus. J Neurosci 18: $10070-10077$.

McDonough JH Jr, Shih TM. 1997. Neuropharmacological mechanisms of nerve agent-induced seizure and neuropathology. Neurosci Biobehav Rev 21: 559-579.

Merritt K, McGuire P, Egerton A. 2013. Relationship between glutamate dysfunction and symptoms and cognitive function in psychosis. Front Psychiatry 4: 151.

Miller HP, Levey AI, Rothstein JD, Tzingounis AV, Conn PJ. 1997. Alterations in glutamate transporter protein levels in kindling-induced epilepsy. J Neurochem 68: $1564-$ 1570.

Miller BR, Dorner JL, Shou M, Sari Y, Barton SJ, Sengelaub DR, Kennedy RT, Rebec GV. 2008. Up-regulation of GLT1 expression increases glutamate uptake and attenuates the Huntington's disease phenotype in the R6/2 mouse. Neuroscience 153: 329-337.

Monory K, Blaudzun H, Massa F, Kaiser N, Lemberger T, Schutz G, Wotjak CT, Lutz B, Marsicano G. 2007. Genetic dissection of behavioural and autonomic effects of $\Delta^{9}$ tetrahydrocannabinol in mice. PLoS Biol 5: e269. 
Moskal JR, Burch R, Burgdorf JS, Kroes RA, Stanton PK, Disterhoft JF, Leander JD. 2014. GLYX-13, an NMDA receptor glycine site functional partial agonist enhances cognition and produces antidepressant effects without the psychotomimetic side effects of NMDA receptor antagonists. Expert Opin Investig Drugs 23: 243-254.

Mula M, Trimble MR, Lhatoo SD, Sander JW. 2003. Topiramate and psychiatric adverse events in patients with epilepsy. Epilepsia 44: 659-663.

Naylor DE, Liu H, Niquet J, Wasterlain CG. 2013. Rapid surface accumulation of NMDA receptors increases glutamatergic excitation during status epilepticus. Neurobiol Dis 54: $225-238$.

Niciu MJ, Ionescu DF, Richards EM, Zarate CA Jr. 2013. Glutamate and its receptors in the pathophysiology and treatment of major depressive disorder. J Neural Transm 121: 907-924.

Niehusmann P, Dalmau J, Rudlowski C, Vincent A, Elger CE, Rossi JE, Bien CG. 2009. Diagnostic value of $N$-methyl-D-aspartate receptor antibodies in women with newonset epilepsy. Arch Neurol 66: 458-464.

Notenboom RG, Hampson DR, Jansen GH, van Rijen PC, van Veelen CW, van Nieuwenhuizen O, de Graan PN. 2006. Up-regulation of hippocampal metabotropic glutamate receptor 5 in temporal lobe epilepsy patients. Brain 129: 96-107.

Obara I, Goulding SP, Hu JH, Klugmann M, Worley PF Szumlinski KK. 2013. Nerve injury-induced changes in Homer/glutamate receptor signaling contribute to the development and maintenance of neuropathic pain. Pain 154: 1932-1945.

Ortuno-Sahagun D, Gonzalez RM, Verdaguer E, Huerta VC Torres-Mendoza BM, Lemus L, Rivera-Cervantes MC, Camins A, Zarate CB. 2013. Glutamate excitotoxicity activates the MAPK/ERK signaling pathway and induces the survival of rat hippocampal neurons in vivo. $\mathrm{J} \mathrm{Mol}$ Neurosci 52: 366-377.

Osterweil EK, Chuang SC, Chubykin AA, Sidorov M, Bianchi R, Wong RK, Bear MF. 2013. Lovastatin corrects excess protein synthesis and prevents epileptogenesis in a mouse model of fragile X syndrome. Neuron 77: 243-250.

Pacey LK, Heximer SP, Hampson DR. 2009. Increased $\mathrm{GABA}_{\mathrm{B}}$ receptor-mediated signaling reduces the susceptibility of fragile $\mathrm{X}$ knockout mice to audiogenic seizures. Mol Pharmacol 76: 18-24.

Pacheco Otalora LF, Couoh J, Shigamoto R, Zarei MM, Garrido Sanabria ER. 2006. Abnormal mGluR2/3 expression in the perforant path termination zones and mossy fibers of chronically epileptic rats. Brain Res 1098: $170-185$.

Piedad J, Rickards H, Besag FM, Cavanna AE. 2012. Beneficial and adverse psychotropic effects of antiepileptic drugs in patients with epilepsy: A summary of prevalence, underlying mechanisms and data limitations. CNS Drugs 26: 319-335.

Pitsch J, Schoch S, Gueler N, Flor PJ, van der Putten H, Becker AJ. 2007. Functional role of mGluR1 and mGluR4 in pilocarpine-induced temporal lobe epilepsy. Neurobiol Dis 26: 623-633.

Pochwat B, Palucha-Poniewiera A, Szewczyk B, Pilc A, Nowak G. 2014. NMDA antagonists under investigation for the treatment of major depressive disorder. Expert Opin Investig Drugs 23: 1181-1192.

Porter BE, Jacobson C. 2013. Report of a parent survey of cannabidiol-enriched cannabis use in pediatric treatment-resistant epilepsy. Epilepsy Behav 29: 574-577.

Potschka H, Krupp E, Ebert U, Gumbel C, Leichtlein C, Lorch B, Pickert A, Kramps S, Young K, Grune U, et al. 2002. Kindling-induced overexpression of Homer $1 A$ and its functional implications for epileptogenesis. Eur J Neurosci 16: 2157-2165.

Proper EA, Hoogland G, Kappen SM, Jansen GH, Rensen MGA, Schrama LH, van Veelen CWM, van Rijen PC, van Nieuwenhuizen O, Gispen WH, et al. 2002. Distribution of glutamate transporters in the hippocampus of patients with pharmaco-resistant temporal lobe epilepsy. Brain 125: $32-43$.

Rawls SM, Karaca F, Madhani I, Bhojani V, Martinez RL, Abou-Gharbia M, Raffa RB. 2010. $\beta$-Lactamase inhibitors display anti-seizure properties in an invertebrate assay. Neuroscience 169: 1800-1804.

Rheims S, Ryvlin P. 2013. Profile of perampanel and its potential in the treatment of partial onset seizures. Neuropsychiatr Dis Treat 9: 629-637.

Rho JM, Donevan SD, Rogawski MA. 1994. Mechanism of action of the anticonvulsant felbamate: Opposing effects on $N$-methyl-D-aspartate and $\gamma$-aminobutyric acid A receptors. Ann Neurol 35: 229-234.

Rogawski MA. 2013. AMPA receptors as a molecular target in epilepsy therapy. Acta Neurol Scand Suppl 197: 9-18.

Rothstein JD, Martin L, Levey AI, Dykes-Hoberg M, Jin L, Wu D, Nash N, Kuncl RW. 1994. Localization of neuronal and glial glutamate transporters. Neuron 13: 713-725.

Rothstein JD, Patel S, Regan MR, Haenggeli C, Huang YH, Bergles DE, Jin L, Dykes Hoberg M, Vidensky S, Chung DS, et al. 2005. $\beta$-Lactam antibiotics offer neuroprotection by increasing glutamate transporter expression. $\mathrm{Na}$ ture 433: 73-77.

Russo I, Bonini D, Via LL, Barlati S, Barbon A. 2013. AMPA receptor properties are modulated in the early stages following pilocarpine-induced status epilepticus. Neuromolecular Med 15: 324-338.

Ryley Parrish R, Albertson AJ, Buckingham SC, Hablitz JJ, Mascia KL, Davis Haselden W, Lubin FD. 2013. Status epilepticus triggers early and late alterations in brain-derived neurotrophic factor and NMDA glutamate receptor Grin2b DNA methylation levels in the hippocampus. Neuroscience 248C: 602-619.

Sari Y, Smith KD, Ali PK, Rebec GV. 2009. Upregulation of GLT1 attenuates cue-induced reinstatement of cocaineseeking behavior in rats. J Neurosci 29: 9239-9243.

Sato M, Suzuki K, Nakanishi S. 2001. NMDA receptor stimulation and brain-derived neurotrophic factor upregulate Homer la mRNA via the mitogen-activated protein kinase cascade in cultured cerebellar granule cells. J Neurosci 21: 3797-3805.

Schousboe A, Madsen KK, Barker-Haliski ML, White HS. 2014. The GABA synapse as a target for antiepileptic drugs: A historical overview focused on GABA transporters. Neurochem Res 39: 1980-1987.

Schratt GM, Tuebing F, Nigh EA, Kane CG, Sabatini ME, Kiebler M, Greenberg ME. 2006. A brain-specific micro- 
RNA regulates dendritic spine development. Nature 439: $283-289$.

Seeburg DP, Feliu-Mojer M, Gaiottino J, Pak DT, Sheng M. 2008. Critical role of CDK5 and Polo-like kinase 2 in homeostatic synaptic plasticity during elevated activity. Neuron 58: 571-583.

Simantov R, Crispino M, Hoe W, Broutman G, Tocco G, Rothstein JD, Baudry M. 1999. Changes in expression of neuronal and glial glutamate transporters in rat hippocampus following kainate-induced seizure activity. Brain Res Mol Brain Res 65: 112-123.

Sroubek J, Hort J, Komarek V, Langmeier M, Brozek G. 2001. Acquisition and retrieval of conditioned taste aversion is impaired by brain damage caused by two hours of pilocarpine-induced status epilepticus. Physiol Res 50: 609617.

Stella N. 2010. Cannabinoid and cannabinoid-like receptors in microglia, astrocytes, and astrocytomas. Glia 58: 1017-1030.

Takahashi DK, Vargas JR, Wilcox KS. 2010. Increased coupling and altered glutamate transport currents in astrocytes following kainic-acid-induced status epilepticus. Neurobiol Dis 40: 573-585.

Tanaka K, Watase K, Manabe T, Yamada K, Watanabe M, Takahashi K, Iwama H, Nishikawa T, Ichihara N, Kikuchi T, et al. 1997. Epilepsy and exacerbation of brain injury in mice lacking the glutamate transporter GLT-1. Science 276: $1699-1702$.

Tang FR, Chia SC, Chen PM, Gao H, Lee WL, Yeo TS, Burgunder JM, Probst A, Sim MK, Ling EA. 2004. Metabotropic glutamate receptor $2 / 3$ in the hippocampus of patients with mesial temporal lobe epilepsy, and of rats and mice after pilocarpine-induced status epilepticus. Epilepsy Res 59: 167-180.

Tu JC, Xiao B, Naisbitt S, Yuan JP, Petralia RS, Brakeman P, Doan A, Aakalu VK, Lanahan AA, Sheng M, et al. 1999. Coupling of mGluR/Homer and PSD-95 complexes by the Shank family of postsynaptic density proteins. Neuron 23: 583-592.

Turrigiano G. 2007. Homeostatic signaling: The positive side of negative feedback. Curr Opin Neurobiol 17: 318 324.

Turrigiano G. 2012. Homeostatic synaptic plasticity: Local and global mechanisms for stabilizing neuronal function. Cold Spring Harb Perspect Biol 4: a005736.

Vargas JR, Takahashi DK, Thomson KE, Wilcox KS. 2013. The expression of kainate receptor subunits in hippocampal astrocytes after experimentally induced status epilepticus. J Neuropath Exp Neurol 72: 919-932.

Vezzani A, French J, Bartfai T, Baram TZ. 2011. The role of inflammation in epilepsy. Nat Rev Neurol 7: 31-40.

Wada Y, Hasegawa H, Nakamura M, Yamaguchi N. 1992. The NMDA receptor antagonist MK-801 has a dissociative effect on seizure activity of hippocampal-kindled cats. Pharmacol Biochem Behav 43: 1269-1272.
Wang SJ, Huang CC, Hsu KS, Tsai JJ, Gean PW. 1996. Inhibition of $\mathrm{N}$-type calcium currents by lamotrigine in rat amygdalar neurones. Neuroreport 7: 3037-3040.

Wasterlain CG, Chen JW. 2008. Mechanistic and pharmacologic aspects of status epilepticus and its treatment with new antiepileptic drugs. Epilepsia 49: 63-73.

Wasterlain CG, Naylor DE, Liu H, Niquet J, Baldwin R. 2013. Trafficking of NMDA receptors during status epilepticus: Therapeutic implications. Epilepsia 54: 78-80.

Wetherington J, Serrano G, Dingledine R. 2008. Astrocytes in the epileptic brain. Neuron 58: 168-178.

White HS, Harmsworth WL, Sofia RD, Wolf HH. 1995a. Felbamate modulates the strychnine-insensitive glycine receptor. Epilepsy Res 20: 41-48.

White HS, Johnson M, Wolf HH, Kupferberg HJ. 1995b. The early identification of anticonvulsant activity: Role of the maximal electroshock and subcutaneous pentylenetetrazol seizure models. Ital J Neurol Sci 16: 73-77.

White HS, Sarup A, Bolvig T, Kristensen AS, Petersen G, Nelson N, Pickering DS, Larsson OM, Frolund B, Krogsgaard-Larsen P, et al. 2002. Correlation between anticonvulsant activity and inhibitory action on glial $\gamma$ aminobutyric acid uptake of the highly selective mouse $\gamma$-aminobutyric acid transporter 1 inhibitor 3-hydroxy4-amino-4,5,6,7-tetrahydro-1,2-benzisoxazole and its $\mathrm{N}$-alkylated analogs. J Pharmacol Exp Ther 302: 636-644.

White HS, Scholl EA, Klein BD, Flynn SP, Pruess TH, Green BR, Zhang L, Bulaj G. 2009. Developing novel antiepileptic drugs: Characterization of NAX 5055, a systemically active galanin analog, in epilepsy models. Neurotherapeutics 6: $372-380$.

Williams PA, White AM, Clark S, Ferraro DJ, Swiercz W, Staley KJ, Dudek FE. 2009. Development of spontaneous recurrent seizures after kainate-induced status epilepticus. J Neurosci 29: 2103-2112.

Xu Z, Cortes R, Villar M, Morino P, Castel MN, Hokfelt T. 1992. Evidence for upregulation of galanin synthesis in rat glial cells in vivo after colchicine treatment. Neurosci Lett 145: 185-188.

Zarate CA Jr, Singh JB, Carlson PJ, Brutsche NE, Ameli R, Luckenbaugh DA, Charney DS, Manji HK. 2006. A randomized trial of an $\mathrm{N}$-methyl-D-aspartate antagonist in treatment-resistant major depression. Arch Gen Psychiatry 63: 856-864.

Zeng LH, Bero AW, Zhang B, Holtzman DM, Wong M. 2010. Modulation of astrocyte glutamate transporters decreases seizures in a mouse model of tuberous sclerosis complex. Neurobiol Dis 37: 764-771.

Zhang L, Robertson CR, Green BR, Pruess TH, White HS, Bulaj G. 2009. Structural requirements for a lipoamino acid in modulating the anticonvulsant activities of systemically active galanin analogues. J Med Chem 52: 1310 1316. 


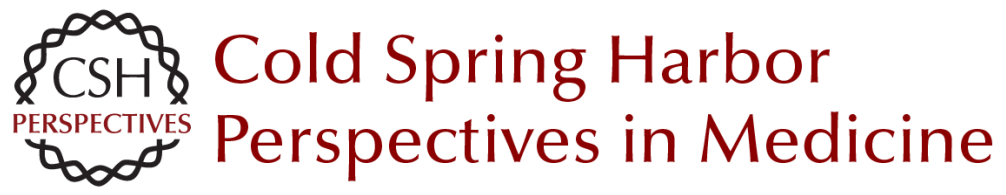

\section{Glutamatergic Mechanisms Associated with Seizures and Epilepsy}

Melissa Barker-Haliski and H. Steve White

Cold Spring Harb Perspect Med 2015; doi: 10.1101/cshperspect.a022863 originally published online June 22, 2015

\section{Subject Collection Epilepsy: The Biology of a Spectrum Disorder}

The Epilepsy Spectrum: Targeting Future Research Challenges

Gregory L. Holmes and Jeffrey L. Noebels

Role of Sodium Channels in Epilepsy

David I. Kaplan, Lori L. Isom and Steven Petrou

\section{Mechanisms of Action of Antiseizure Drugs and the Ketogenic Diet \\ Michael A. Rogawski, Wolfgang Löscher and Jong M. Rho}

Epilepsy and Autism

Ashura W. Buckley and Gregory L. Holmes

Immunity and Inflammation in Epilepsy Annamaria Vezzani, Bethan Lang and Eleonora Aronica

Hyperpolarization-Activated Cyclic

Nucleotide-Gated (HCN) Channels in Epilepsy Gary P. Brennan, Tallie Z. Baram and Nicholas P. Poolos

The Role of Calcium Channels in Epilepsy Sanjeev Rajakulendran and Michael G. Hanna

Interneuron Transplantation as a Treatment for Epilepsy

Robert F. Hunt and Scott C. Baraban
Common Mechanisms Underlying

Epileptogenesis and the Comorbidities of

Epilepsy

Andrey Mazarati and Raman Sankar

The Diathesis-Epilepsy Model: How Past Events Impact the Development of Epilepsy and

Comorbidities

Christophe Bernard

Potassium Channels in Epilepsy

Rüdiger Köhling and Jakob Wolfart

GABAergic Synchronization in Epilepsy Roustem Khazipov

Status Epilepticus

Syndi Seinfeld, Howard P. Goodkin and Shlomo Shinnar

Neonatal and Infantile Epilepsy: Acquired and

Genetic Models Aristea S. Galanopoulou and Solomon L. Moshé

Epigenetics and Epilepsy

David C. Henshall and Katja Kobow

Microcircuits in Epilepsy: Heterogeneity and Hub Cells in Network Synchronization

Anh Bui, Hannah K. Kim, Mattia Maroso, et al.

For additional articles in this collection, see http://perspectivesinmedicine.cshlp.org/cgi/collection/ 